\title{
SEISMIC DESIGN COMMITTEE
}

\section{INTRODUCTION}

The Management Committee of the New Zealand National Society for Earthquake Engineering have for some time planned the formation of a Seismic Design Committee. It is the intention that this Committee would offer assistance to Local Authorities and to designers, for designs of structures and other developments in seismic engineering which border on present knowledge or which are not covered in accepted codes or texts. The Committee may also assist in providing interpretation of code requirements both to overall concepts and to matters of detail.

There is no intention that the Design Committee should take away the normal function of Local Bodies. It is intended to be complementary to, but never in competition with them.

At its meeting on 6 April, 1978, the Management Committee confirmed the constitution and code of ethics of the Seismic Design Committee and its design guidelines. These are set out below.

Inquiries are invited and should be addressed to :-

The Secretary,

Management Committee of the New Zealand National Society for Earthquake Engineering,

P.O. Box 243 ,

Wellington.

\section{CONSTITUTION, PROCEDURE, CODE OF ETHICS}

\section{A. Introduction}

The Seismic Design Committee, earlier referred to as the High Rise Building Committee, was first proposed following the original report by Mr. W. P. Edwards in 1967.

Following the promulgation of the ductility hypothesis in the 1950's and commercial pressures for buildings of considerably greater height than before, a High Rise Building Review Committee was formed in Japan in the $1960^{\prime} \mathrm{s}$ to review the designs of high rise buildings. It was charged with ensuring as far as possible that proposed tall buildings would safely withstand earthquake shocks.

The committee was legally established to report to the Minister of Construction, who has final authority. It now consists of twenty-four members, who are drawn, almost without exception, from the Universities.

Having the reputation of being highly competent, the Japanese Review Committee had, by Febrary, 1975, completed reviews of more than two hundred and fifty tall buildings.

The form of presentation to the Review Committee has become more or less standardised. It has been based on examples of cases which have been approved in the past. The documents and drawings as submitted by the designer, and the final report of the Review Committee, are filed at the Building Centre of Japan, and may be inspected there by interested persons. A case is not favourably reported on until the sub-comittee and the full committee are satisfied. Revisions and additional work are requested before final approval. Final reports are published from time to time in the Building Letter, a magazine subscribed to by duespaying members of the Building Centre.

This system has evolved from the practical necessity for such an arrangement, and has the full co-operation and approval of Local Authorities who are glad to take advantage of the expertise of the committee.

\section{B. Application to New Zealand}

In these days of rapidly advancing technology, codes and by-laws are often many years behind desirable practice. Local Authorities occasionally find themselves in the position of having to give a building permit for a design which complies with their by-laws, but on which their technical staff have considerable reservations. On occasions, pressure is brought to bear to cause Local Body Officers to accept designs which should not get approval.

There is often doubt about the applicability or meaning of code provisions, or there may not even be any code provision to cover the point in question. Where by-laws are inadequate the Local Authority has no power to enforcea higher standard.

Building permits are often required, not only for tall structures, but also for buildings of unusual types of materials, sites or designs which are outside the scope of the by-laws.

In the opinion of the Management Committee of the New Zealand National Society for Earthquake Engineering, the opinions and combined knowledge of a widely based group of specialists could bring to bear expertise and know-how which could assist Local Bodies and designers.

It is with the object of satisfying these needs that the Seismic Design Committee has been formed. 
Statutory backing for the Committee has not been sought. It is considered that applications may be made to the Committee at the discretion of the Local Authority Engineer, or the Designers.

The New Zealand Committee has a wider representation than that in Japan, using co-opted members whereadvisable, and with a sufficient spread of men with practical design experience.

There is no intention that the committee should take away the function of Local Bodies. It should be complementary to, but never in competition with them. In effect it should act as a "back-stop" when the Local Authorities feel they require to draw on advice from a panel with special knowledge and expertise. To make use of the committee, and to be able to charge for the expenses incidental to a review, councils will need to enact a by-law giving them power to do so. This can be done under the empowering provisions of either the Municipal Corporations or the Counties Act.

Normally an application for review will first be made by the Local Authority or the Designer at the Sketch Plan stage of the design, to avoid wasted design effort. This can be operated in a similar manner to the preliminary discussions and structural checking that many councils offer.

This procedure will entail the Committee being asked at an early stage what principles and procedures it finds acceptable.

It is therefore the intention of the Committee that it should codify its experience and findings, to serve as a guide to code writing committees and allow the repeated use of the fruits of earlier efforts.

\section{Constitution of the Seismic Design Committee}

\section{Object}

The object of the committee is to ensure as far as practicable that the seismic design principles of the whole or of any aspect of any tall or unusual structure submitted to it for review are structually sound and in conformity with the best design practice.

\section{C2. Authority}

The Committee has been established under the auspices of the N.Z. National Society for Earthquake Engineering. Approval by the Committee implies that the seismic design principles employed are likely to be in conformity with the best available knowledge in New Zealand at the time.

\section{C3. Personnel}

The Committee shall be comprised of at least eight members (who shall have power to co-opt) plus a Secretary, who shall all be appointed by the Management Committee of the N.Z. National Society for Earthquake Engineering. Length of service and payment shall be at the discretion of the said Management Committee. The Seismic Design Committee shall elect a chairman from its members.

\section{C4. Secretariat}

The Seismic Design Committee shall employ a secretariat to whom all correspondence shall be addressed.

\section{C5. Meetings}

The meetings of the Committee shall be held in Wellington or in such other centre as considered expedient, as necessary.

C6. Quorum

At least four at a meeting.

\section{C7. Finance}

The expenses incurred by the committee in processing each application shall be to the account of each applicant. Payment shall be due on completion of the review.

\section{C8. Procedure}

A description of the procedure shall be available from the secretary.

\section{C9. Ethics}

Members of the Seismic Design Committee shall be governed by the committee's code of Ethics.

\section{C10. Appeals}

Each applicant shall have the right to a re-hearing, if necessary, at his own expense.

\section{Procedure for Applications for Reviewal}

Dl. A "Preliminary Design Guidelines" outline is available from the secretary, together with a Reviewed Contract Note and an Application Form. An application shall be made in the name of the Designer. (The Seismic Design Committee shall determine a suitable review procedure for each application.)

D2. Prior to submitting a design for reviewal, all Local Authority requirements other than structural, viz. town planning. egress, fire resistant construction, etc., should be complied with.

D3. An application consisting of three sets of plans (sufficient to describe all salient features of the building) design calculations and supporting description should be sent to the Secretary, who shall send one set to the Chairman. The scope of the review shall be recorded by the committee.

D4. The Secretary will advise the applicant when and where the hearing will be heard, and give preliminary advice, where possible, of the Committee's initial response.

D5. Applicant will attend the Committee meeting to explain, and answer questions. The Secretary to record as minutes. Minutes to be confirmed.

D6. Committee will deliberate and advise applicant of decision. 
D7. Final plans shall be submitted with a certificate from the Designer to certify that the design conforms to the Minutes and the spirit of the Committee's requirements, or otherwise stating what has been varied.

D8. A re-hearing may be held if required.

D9. Sets of documents shall be stamped as approved. One set shall be kept, one returned, and one sent independently to the Local Authority, with the opinion of the committee.

DI0. The Local Authority checks and issues the building permit in the normal way.

\section{E. Commentary}

E1. Name

The intention is that the committee should be the highest review authority in New Zealand for the seismic design of tall or unusual structures.

\section{E2. Object}

It has been found impossible so far to codify all the requirements for sound seismic design, hence mere compliance with the letter of any building code does not necessarily result in sound design. The committee should be considered as being complementary to the work of the local structural checking officials. Its findings should be codified, where practicable.

\section{E3. Authority}

The N.Z. National Society for Earthquake Engineering is a Technical Group of the N.Z. Institution of Engineers, and has a membership drawn from all disciplines relevant to earthquake engineering. The Committee does not have statutory authority, but any applicable work proceeding with the design sanction of the committee will benefit from the standing the sanction will give.

\section{E4. Personnel}

For economy, it is considered best to keep the numbers of personnel on the committee to a minimum, consistent with achieving a sufficient breadth of knowledge. A small committee ensures closer personal involvement and reduced cost. It is likely that a subcommittee of only a few experts will be established for each particular review.

\section{E5. Secretariat}

The Administrative Secretary of the New Zealand National Society for Earthquake Engineering has been appointed Secretary of the Seismic Design Committee.

\section{E6. Meetings}

These probably will be held at the N.Z. Institution of Engineers Board Room, Molesworth House, Wellington, unless notified otherwise.

\section{E7. Finance}

Costs pertaining to each reviewal shall be to the account of the Applicant.

\section{F. Code of Ethics}

\section{F1. The Public Interest}

A member's responsibility to the Committee shall have full regard to the public interest.

\section{F2. Matters of Fact}

If called upon to speak on a matter of fact, the member shall speak what he believes to be the truth.

\section{F3. Matters of Opinion}

A member shall refrain from expressing opinions which reflect adversely on the ability or integrity of other engineers, or which are not based on full knowledge of the facts.

\section{F4. Diligence}

Each member shall diligently apply his skill and knowledge to the best interests of each case considered.

\section{F5. Limitations}

Where a member is confronted by a problem which calls for knowledge and experience which he does not possess, he shall inform the Committee of the fact and shall recommend the desirability of obtaining further advice.

\section{F6. Impartiality}

A member shall take care to avoid any circumstances which might affect the impartiality of his judgement. He shall fully disclose circumstances of any nature, financial or otherwise, which might appear likely to influence the impartiality of his advice.

\section{F7. Acceptance of Favours}

A member shall at all times avoid placing himself under any obligations to any person or firm in his service on behalf of the Committee. He shall not accept any gift, remuneration or gratuity from such person or firm.

\section{F8. Conflict of Interest}

A member shall not adjudicate on any case in which he is otherwise in any way associated with.

\section{F9. Advertising}

A member shall not advertise that, nor solicit business on the grounds that he is a member of the committee.

\section{Model By-Law}

Local Authorities may elect to pass a by-law empowering them to make use of the Seismic Design Committee and to pass on its charges. A model form of such a by-law is as follows :

"In the event of a Building Permit application being received for a building the seismic design of which, in the opinion of the Engineer, is not adequately provided 
for in the Council's existing by-laws, the Engineer may, at his discretion, require that the seismic design be to the approval of the Seismic Design Committee. All expenses involved in the satisfaction of this requirement shall be borne by the Applicant."

\section{H. Applications}

Applications for reviewal should be addressed to:

The Secretary,

New Zealand Seismic Design Committee, P.O. Box 243,

Wellington.

\section{DESIGN GUIDELINES.}

The following guidelines are intended to be used where there are at present no New Zealand By-Laws or Regulations covering the proposed design.

\section{Aim}

1.1 It is the aim of the Seismic Design Committee to give guidance to designers and to Local Authorities on designs for structures which border on present knowledge or which are not covered in accepted codes or texts. The Committee may also assist in providing interpretation of code requirements. To this end a sub-committee will be selected appropriate to the particular task to give advice on a job by job basis. In practice quite different groups will be formed for bridging, for buildings, for civil structures or for other special structures or parts thereof. The Seismic Design Committee believes it can be of most help if its advice is sought early in the formation stage and before designs are fully committed to documentation or even construction.

1.2 The Committee will review designs only with regard to the philosophy employed in overall structural design and detailing. The Committee will not carry out checks to confirm numerical correctness for adequacy of detailing.

The Committee may at its option however request the submission of more detailed information to clarify the philosophy or request that additional calculations be carried out or that all or part of the work be reviewed in detail by an independent checker.

The Committee may request that model or large scale tests be carried out.

1.3 The committee in reviewing designs will be guided by the following:

The design should meet wherever possible the requirements of the current SANZ codes of practice or such SANZ drafts or portions of drafts as the Committee may decide to be applicable to the proposal. The Committee may accept relevant overseas codes.

The information supplied to the Committee should where appropriate include reports on the site by a suitably qualified geologist, soil mechanics engineer and if required from such other experts as the Committee may nominate.

\section{General}

2.1 The object of the design should be:

(a) to avoid injury or loss of life

(b) to minimise damage to property

(c) to ensure continuity of vital services at all times.

2.2 The following local conditions should be considered:

(a) seismological, geological and climatic conditions

(b) economy of design and construction consistent with fulfilling the objects of the design.

\subsection{Other considerations:}

(a) design methods shall be rational

(b) structural arrangements should be such that they can be analysed with confidence.

(c) the experience of others should be considered wherever relevant

(d) exploit existing experience to the greatest extent possible.

(e) where non-standard approaches are involved, research the subject thoroughly through technical publications

(f) comply with the spirit of any relevant codes or papers.

2.4 Use of the following documents, where appropriate, is recommended:

(a) NZS 4203:1976 "General Structural Design and Design Loadings for Buildings".

(b) NZS 3404:1977 "Code for Design of Steel Structures" .

(c) ACI 318-7I (and amendments) "Building Code Requirements for Reinforced Concrete" or preferably the SANZ draft of the N.Z. Concrete code where available.

(d) appropriate papers in the proceedings of ACI and ASCE.

(e) papers published in technical journals including the latest bulletins of NZNSEE, especially those giving recommendations on $\mathrm{R} . \mathrm{C}$. ductile frame design.

\section{Site Selection}

3.1 Where a choice of sites is possible, consideration should be given to the following:

(a) seismicity

(b) geotectonic and geological conditions

(c) presence of known active fault lines

(d) subsoil conditions.

\subsection{Seismicity}

Investigate detail of seismicity of locality and take account of special factors in recorded data.

\subsection{Geotectonic and geological conditions}

Take due consideration of geological irregularities, such as fault lines, or areas of potential danger due to landslide or tsunami.

\subsection{Subsoil conditions}

Ensure subsoil conditions are fully 
investigated.

Consider swelling and shrinkage due to seasonal changes, and the effects of high pore-water pressures.

The dynamic characteristics of the subsoil should be considered in relation to the type of structure and its foundations.

Areas subject to large or differential settlement due to earthquake should be avoided.

Consider the effects of likely soil deformations with respect to the foundations and structure. soils.

Consider methods for modifying unstable

\section{General Planning}

\subsection{Layout}

The structure should have a simple, regular layout, in both plan and elevation arrangement and be adequately redundant. The plan should preferably be symmetrical, or anti-symmetrical. The structure should not be too long or slender.

\subsection{Basic Planning}

(a) Subject to the constraints of planning and economics the structural type should be that best suited to the underlying foundation soils.

(b) Where predominant characteristics of ground motion are known structures highly responsive to these should be avoided where possible. The structure should be adequately stiff to avoid damaging floor motions and/or panic amongst occupants.

(c) The centre of mass should coincide with the centre of rigidity, as nearly as possible. Make allowance for variations from estimated stiffnesses on account of non-elastic deformations.

(d) The structure preferably should not have sudden chances in strength or stiffness.

(e) Planning should be such as to minimise the possibility of later structural and non-structural changes which could affect the performance of the structure.

(f) The structure should be as insensitive as practical to uncertainties in input motions and unavoidable departures from "ideal" member strengths.

(g) The preferred structural arrangement shoula be such as to distribute energy absorption as widely as possible, and provide the most damping.

(h) All structural elements should have sufficient strength, and stiffness for the assumed transmission of all forces.

\subsection{Irregular Structures}

Irregularities should be minimised wherever possible. This may be achieved by division into separate regular entities. When an irregular structure is unavoidable, it should be designed to act as an integral unit, and full consideration should be given to torsion anà post elastic effects.

\subsection{Foundations}

The foundation of a structure should preferably be constructed of a single type of foundation system. The foundation elements should be adequately tied together and designed and constructed to act integrally with the structure, especially on flexible ground.

\subsection{Materials}

Structures should be constructed of materials, or combinations of materials, that are permanent, and have sufficient strength and ductility to resist earthquake forces.

\subsection{Fire Resistance}

Structures that could be affected by fire following an earthquake should be appropriately fire-resistant.

\section{Seismic Analysis}

\subsection{Methods of Seismic Analysis}

In general, a dynamic analysis by a spectral modal analysis is recommended. This may need to be supplemented by a numerical integration response analysis. The structural model and the earthquake trace appropriate to the site should be carefully selected or a range of possibilities considered.

\subsection{Direction of Design Seismic Forces}

Earthquake forces may act on a structure from any direction, in plan, and consideration should be given to vertical earthquake effects for special structures.

The concurrent effects of forces along two principal axes should be considered.

All probable cases of loadings, and their combinations, should be taken into account with appropriate factors of safety to suit the probabilities of those combinations.

\subsection{Determination of Design Seismic Forces}

Design seismic forces, where not clearly established by N.Z. Standards or Codes of Fractise, should be selected after consideration of the following:

(a) the seismicity of the site

(b) the expected life of the structure and consequences of failure or unserviceability under a larger than desion earthquake

(c) dynamic response characteristics of the structure, allowing for the interaction between it and the subsoil

(d) the energy absorbing capacity of the structure in the elastic and non-elastic ranges

(e) earthquake shock wave compression and tension effects in long structures

(f) effect of uncertainties due to input parameters and due to the assumptions made.

If practicable, consider isolation of the structure from the earthquake forces by a suitable system of base isolation.

Where this is not possible, design the structure bearing in mind that the seismic 
forces and displacements may be several times the usual code forces. The excess force may be absorbed by ductile yielding only if this is provided for.

\subsection{Loads and External Forces to Be Consid- ered in Seismic Analysis}

For the seismic analysis of structures, normal loads should be considered in combination with the following loads:

(a) Earthquake inertia forces due to dead weight and live load. Use the probable overall liveload for overall analysis, and the maximum live load for the design of individual elements. Progressively reduce the effects of full live load with distance from the element to allow for the probability that all elements do not support maximum live load at once. Include snow loads where applicable.

(b) Earth pressures due to earthquake.

(c) Hydrodynamic pressures due to earthquake.

Earthquake and wind forces need not be assumed to act at the same time.

\subsection{Methods of Structural Analysis}

The level of analytical complexity may range from simple linear elastic static analysis under equivalent seismic forces, through spectral modal analysis, to full inelastic time-history analysis, depending on the structural complexity and importance. Structures with marked lack of symmetry should be subject to three-dimensional analysis.

\subsection{Structural Detailing}

Member sizes shall be such as to keep deformations within acceptable limits. It is essential that failures of the sudden or brittle type be avoided. Failures of the sudden shear, compression, bond or buckling types shall not be allowed unless the individual components can accept the full elastic earthquake response from an approved series of earthquake spectra with acceptable factors of safety. Rather, members should fail by gradual progressive yielding.

In framed structures columns should be made adequately stronger than the beams framing into them, except that some columns may be allowed to yield if sufficient columns in a bent are fully protected.

Bolted joints in structural steelwork should either be made stronger than the members connected, or the parts connected should be made to yield before the bolts.

The effects of temperature, shrinkage and creep should be allowed for.

Failure due to metal fatigue or due to metallurgical (strain ageing) causes should be guarded against.

The effects of friction shall be fully allowed for. This is especially important in wall panel connections.

The design of joints and connections shall be adequate for their purpose. factor of safety shall be employed consistent with their situation.
Provisions for mechanical, electrical and architectural fittings and fixings must not weaken the structure. In particular, rebates, chases, grooves, inserts, conduits, downpipes, sleeves, pipe and duct penetrations etc. shall not be permitted if they reduce the integrity of the structure.

The design shall preferably permit easy repair in the event of earthquake damage.

\subsection{Supervision of Construction}

The Committee should be advised of the proposed arrangements for structural supervision and inspection of the work. 